\title{
Title:
}

\section{Impact of flooded rice paddy on remotely sensed evapotranspiration in the Krishna River Basin, India}

Pardhasaradhi Teluguntla $^{1^{*}}$, Dongryeol Ryu ${ }^{1 *}$, Biju George ${ }^{1}$ and Jeffrey P. Walker ${ }^{2}$

${ }^{1}$ Department of Infrastructure Engineering, The University of Melbourne, Victoria, Australia;

E-Mails: teluguntlasaradhi@gmail.com; dryu@unimelb.edu.au; biju@unimelb.edu.au

2DDepartment of Civil Engineering, Monash University, Victoria, Australia; E-Mail: jeff.walker@monash.edu;

*Author to whom correspondence should be addressed; E-Mail:

teluguntlasaradhi@gmail.com;dryu@unimelb.edu.au

\section{Running title:}

Impact of flooded rice paddy on remotely sensed evapotranspiration

This is the author manuscript accepted for publication and has undergone full peer review but has not been through the copyediting, typesetting, pagination and proofreading process, which may lead to differences between this version and the Version of Record. Please cite this article as doi: 10.1002/hyp.13748

This article is protected by copyright. All rights reserved. 


\begin{abstract}
:
Evapotranspiration (ET) is one of the major water exchange processes between the earth's surface and the atmosphere. ET is a combined process of evaporation from open water bodies, bare soil and plant surfaces, and transpiration from vegetation. Remote sensing-based ET models have been developed to estimate spatially distributed ET over large regions, however, many of them reportedly underestimate ET over semi-arid regions (Jamshidi et al., 2018). In this work, we show that underestimation of ET can occur due to the open water evaporation from flooded rice paddies ignored in the existing ET models. To address the gap in ET estimation, we have developed a novel approach that accounts for the missing ET component over flooded rice paddies. Our method improved ET estimates by a modified Penman-Montieth (PM) algorithm that considered the fraction of open water evaporation from flooded rice paddies. Daily evapotranspiration was calculated using ground based meteorological data and the MODIS satellite data over the Krishna River Basin. Seasonal and annual ET values over the Krishna Basin were compared with two different ET algorithms. ET estimates from these two models were also compared for different crop combinations. Results were validated with flux tower-based measurements from other studies. We have identified a $17 \mathrm{~mm} /$ year difference in average annual ET over the Krishna River Basin with this new ET algorithm. This is very critical in basin scale water balance analysis and water productivity studies.
\end{abstract}

Keywords: flooded rice paddy; evapotranspiration; MODIS; remote sensing ET; Krishna River Basin.

This article is protected by copyright. All rights reserved. 


\section{Introduction}

Evapotranspiration (ET) is one of the major water exchange processes between the earth's surface to the atmosphere and it is the collective process of evaporation from bare soils, open water bodies, and plant surfaces and transpiration from vegetation ( $\mathrm{Li}$ et al., 2009). ET is an important component of the hydrologic processes and plays a substantial role in regional and global climate through hydrological circulation. Reliable estimates of ET is required to solve several issues in agriculture, hydrology, water management, and climate studies (e.g., Allen et al., 1998, Gowda et al., 2008). ET is a key variable in estimation of crop coefficients and crop water requirements (Marek et al., 2006)

Precise estimation of ET is essential particularly in the water balance at the watershed to continental scales studies for scheduling and manage water resources. For example, precise estimation of ET for irrigated croplands is critical for water allocation, irrigation scheduling, assessing the water productivity, developing best management practices to reduce surface and groundwater deprivation, and assessing the impacts of agriculture management practices on water resources (Bastiaanssen et al., 2005).

There are many ET methods which can be categorized into two groups. 1. Conventional methods and 2. Satellite based ET algorithms. Conventional methods use surface meteorological data from ground stations. However, they are typically point measurements and consequently represent only a minor fraction of the landscape. To overcome shortcomings of conventional methods, satellite based ET algorithms can be used to calculate ET over large scales since remote sensing data measures a much larger area than possible with surface measurements; satellite derived parameters often used to calculate ET include 
vegetation index and the land surface temperature (Allen et al., 2007a; Kustas et al., 1998; Tasumi et al., 2005).

Surface Energy Balance (SEB) are a group of satellite-based ET algorithms which use land surface temperature (LST) and are frequently used in water resources management. SEB models include: Surface Energy Balance System (SEBS) (Su, 2002), Surface Energy Balance Algorithm for Land (SEBAL) (Bastiaanssen et al., 1998a, b), Simplified surface Energy Balance (SSEB) (Senay et al., 2004, Senay et al., 2013), and Mapping EvapoTranspiration at high Resolution with Internalized Calibration (METRIC) (Tasumi et al., 2005; Allen et al., 2007a, b). The major limitation of SEB models is that they require uniformly hot and cold pixels within the scene for reference. This necessitates medium to high resolution thermal infrared (TIR) data to provide reliable ET estimates in which the Landsat 7 60-m TIR band is the most common source. However, Landsat 7 only constantly collects imagery every 16 days. Furthermore, since TIR cannot accurately measure LST through clouds, the effective imagery collection in the tropics (largely cloudy) is limited to a few acquisitions over a crop season (Kalma et al., 2008; Allen et al., 2007b). Due to the large pixel size of coarseresolution imagery, it is difficult to find wet areas where latent heat flux can be assumed to be maximum and dry areas where latent heat flux can be assumed to be zero. However, due to frequent image acquisition, cloud free imagery is much more likely to be acquired than higher resolution imagery with less frequent revisit times. Given the above limitations, it may not be feasible to use SEB models to estimate sub-seasonal fluctuation of ET at large scales.

In recent decades, several studies developed ET models using remote sensing data from Advanced Very High Resolution Radiometer (AVHRR) and MODIS satellite images and 
eddy covariance flux towers to estimate spatially distributed ET over larger regions (Cleugh et al., 2007; Leuning et al., 2008; Ferguson et al., 2010; Vinukollu et al., 2011; Mu et al., 2011; Teluguntla et al., 2013). However, many of them reportedly underestimate ET over semi-arid regions (Jamshidi et al.,2018). Many of these methods depend on Leaf Area Index (LAI) and other empirically derived parameters integrated into the Penman-Monteith (PM) model. For example, Teluguntla et al. (2013) used spatially distributed ET estimates from a modified PM model with biome-specific conductance estimated using the Normalized Difference Vegetation Index (NDVI) to analyse water balance. However, Teluguntla et al. (2013) identified an important limitation of the model from the analysis of basin scale ET: the basin water balance resulted in a large overestimation of stream discharge, which indicated an underestimation of the basin-scale ET.

We hypothesize that ET underestimation is partly caused by the modified PM model that doesn't account for the unique cultivation practice of the paddy rice widespread in India. Unlike most other crop fields, the rice paddy maintains ponded surface state for the $55 \%-60 \%$ of the whole growing period. The LAI-based parameterization of the canopy resistance employed in the modified PM model does not consider the influence of the ponded surface and consequently may result in reduced ET from the combined canopy and water surface, particularly in the semi-arid climate (Moratiel and Martínez, 2013). Consequently, it is necessary to improve the ET models relying on the biome-specific conductance parameterization to account for rice paddies or similar surface conditions.

Rice is a main calorie source for over 50 percent of the world's population (IRRI, 2006). About 154 million ha of rice was harvested across the world in 2010, out of which about 40 
percent was harvested in South Asia (Gumma et al., 2011c) and overall about 88 percent was harvested in Asia. The majority of the rice paddy area in South and Southeast Asia are flood irrigated (Muturt and Fairhurst, 2002, Mahanty, 2014), which means that the fraction of the open water evaporation is relatively high. Due to the higher fraction of ET from open water in flooded rice paddies, it is likely that the existing ET algorithms/models underestimate ET over the rice-dominant regions in Asia. This is especially important in South and Southeast Asia as this may add significant uncertainty to the regional-to-continental water budget and subsequent water management and planning. Thus, a deeper understanding of the uncertainty of ET estimates might help to well determine water availability for agriculture. This work aims to improve the modified PM algorithm (Teluguntla et al., 2013, Zhang et al., 2010) to account for the fraction of open water evaporation from flooded rice paddies. This can help water resource managers and water allocation authorities make more informed decisions to supply water in scarce or crisis situations.

This study estimates ET by combining MODIS imagery and ground-based meteorological data. The 8-day composites of 250m NDVI derived from MOD09Q1 product are used for the period June 2000 to May 2007. A new ET model is applied in the Krishna River Basin, India to estimate the basin-scale ET over this time period. We have gathered a good set of ground based daily meteorological data from three different sources for the study period. This paper describes the novel approach that was used for estimating the spatially distributed ET to account for the fraction of open water from flooded rice paddies and compared annual ET for different crop combinations. 


\section{Study Area and Dataset}

\subsection{Study area}

Our current study conducted in the Krishna River Basin (Figure 1), which is one of the largest river basins of India in terms of drainage area. The study area is s located in the southern part of India lying between eastern longitudes $73^{\circ} 15^{\prime} \mathrm{E}$ and $81^{\circ} 15^{\prime} \mathrm{E}$, and northern latitudes $13^{\circ} 05^{\prime} \mathrm{N}$ and $19^{\circ} 20^{\prime} \mathrm{N}$. The geographical area covers four Sothern states including Maharashtra, Karnataka, Andhra Pradesh, and the newly formed Telangana State. Approximately about 265, 272 sq. km of total geographical area (Gumma et al., 2011a). The river Krishna is an east flowing river originating in the western Ghats that drains towards east and finally merge in the Bay of Bengal. The climate is primarily semi-arid along with some sub humid areas in the eastern region and some humid regions in the western region of the basin. Mean precipitation is about $800 \mathrm{~mm}$ per year (Teluguntla et al., 2015). Cropping occurs in two main seasons called kharif and rabi (Gumma et al, 2011a). Also, there is some cropping during summer months (April and May), but it is not considered in this study.

Rice paddy is one of the main irrigated crops grown in the study area. Some farmers grow rice in kharif, some farmers grow in rabi (called single crop rice) or in both seasons (called double crop rice) depending on availability of water. Most of the rice crop is grown under flooded irrigation either by surface or ground water. There are some other irrigated crops also grown in the study area, which include commercial crops such as cotton, sugarcane, chilies, fodder grass, and pulses etc., (Teluguntla et al., 2015). Whereas dryland crops such as millets, sorghum, oilseeds, legumes are grown in the rainfed areas.

This article is protected by copyright. All rights reserved. 


\subsection{Datasets and Description}

\subsubsection{Meteorological Data}

Remote sensing-based ET models primarily require climatological variables from ground stations and vegetation parameters from remote sensing products as inputs. We have acquired ground based meteorological data from three different sources for this study. The complete set of daily metrological data available from ground stations in the study area (Figure 1) was obtained from the Indian Metrological Department (IMD) provided by the Govt of India. In addition, we also obtained daily meteorological data from two other national and international research institutions for the study period.

\subsubsection{MODIS surface reflectance data}

Moderate Resolution Imaging Spectroradiometer (MODIS) is an optical sensor with the Terra and Aqua satellites. MODIS scans the entire surface of the Earth twice per day, once per satellite, acquiring data in 36 spectral bands. The first seven bands of MODIS are designed for the study of land surfaces and vegetation. Of these, four bands including red, near infrared (NIR), blue and short-wave infrared (SWIR) (Table 1) capture the seasonal variations in vegetation vigor, surface water, and soil moisture that characterize key stages of agriculture. The MODIS 8-day composites from the Terra satellite was used in this work. We have used the 250-m MOD09Q1 8-day product for red and NIR bands, the $500 \mathrm{~m}$ MOD09A1 8-day product for blue, and SWIR bands. The 8-day composites of MODIS products MOD09Q1 and MOD09A1 were downloaded from http://modis-land.gsfc.nasa.gov for the study period. We have resampled blue and SWIR bands to 250m spatial resolution since red and NIR band data are available in $250 \mathrm{~m}$ spatial resolution. As we have used 8- 
day composite products, we have 46 composites for each year. We have calculated the following indices for every 8-day period using surface reflectance values from the red, NIR, blue, and SWIR bands.

$$
\begin{aligned}
& N D V I=\frac{N I R-R E D}{N I R+R E D} \\
& E V I=2.5 \frac{N I R-R E D}{N I R+6 * R E D-7.5 * B L U E+1} \\
& L S W I=\frac{N I R-S W I R}{N I R+S W I R}
\end{aligned}
$$

\subsubsection{Land use land cover map}

Land use and land cover (LULC) maps are one important input for Modified PM based ET estimates. We have used time series of MODIS 250m, 8-day composite data for the year 2000-01 and applied the methodology developed by Thenkabail et al., (2007), Biggs et al., (2006), and Gumma et al., (2011a, 2011b) to produce LULC maps for this study. The LULC map composed of 12 different land classes was derived from the MODIS 250m, 8-day maximum value composites data and used it in ET retrieval.

\subsubsection{Flooded rice paddy map}

A flooded rice paddy map is a key input for the new ET algorithm development in this study. We have adopted methodology established by Teluguntla et al., (2015) to map flooded rice paddies in our study area with MODIS 250m 8-day composite time series data. With this we have produced seasonal flooded rice paddy maps for the study region from 2000-01 to 2006-07. 


\section{Methods}

\subsection{Evapotranspiration Algorithm}

Prior to this study in the same study region, Teluguntla et al., (2013) used ET algorithm developed by Zhang et al. (2010) as a baseline to estimate ET by using local ground based meteorological data and Global Inventory Modeling and Mapping Studies (GIMMS) AVHRR NDVI data to improve ET estimates. But the algorithm fails in accounting for the evaporation fraction from open water covered by canopy. To address the gap in ET estimation, with this research, we have established a novel algorithm that accounts for the fraction of open water evaporation from flooded rice paddies.

\subsection{Weighted canopy method}

For estimating evapotranspiration from sparse canopy, Shuttleworth and Wallace (1985) developed an approach (SW) that separates evapotranspiration into two components, soil evaporation and transpiration. Wessel and Rouse (1994) also developed a similar approach (WR) but accounted for evaporation from both soil and the water surface as well.

First open water evaporation is estimated using Prestley and Taylor model for water body pixels.

PT equation is used to calculate open water evaporation from

$$
\lambda E_{\text {openwater }}=a \frac{\Delta A}{\Delta+\gamma}
$$

$\lambda E_{\text {openwater }}$ is the latent heat flux of open water , $A$ is available energy, $\Delta=d e_{\text {sat }} / d T$ the slope of the curve relating saturated water vapour pressure $\left(e_{\text {sat }}\right)$ to air temperature $(\mathrm{T}), \gamma$ is psychometric constant. 
Now the available energy $(A)$ for the non-flooded rice paddy pixels area is linearly partitioned into two energy components canopy $\left(A_{\text {canopy }}\right)$ and soil surface $\left(A_{\text {soil }}\right)$ using fractional vegetation cover ( $f v c$ ) (Mu et al., 2007) as follows

$$
\begin{aligned}
& A_{\text {canopy }}=A \times f v c \\
& A_{\text {soil }}=A \times(1-f v c) .
\end{aligned}
$$

For the flooded rice paddy pixels, on the other hand, the available energy $(A)$ is linearly partitioned into $A_{\text {canopy }}$ for canopy and $A_{\text {soil }}$ for soil before rice transplantation and one week after last irrigation. During irrigation period (after transplantation and end of irrigation), the available energy ( $A$ ) is linearly partitioned into $A_{\text {canopy }}$ for the canopy and $A_{\text {openwatere }}$ for open water using fractional vegetation cover. Soil surface can be assumed to be zero from transplantation season to last irrigation. Open water evaporation is assumed to be zero before transplantation and two weeks after last irrigation application for flooded rice paddy pixels.

$$
A_{\text {openwater }}=A \times(1-f v c)
$$

So total energy ( $A$ ) for before transplantation of rice and one week after last irrigation is $A=A_{\text {canopy }}+A_{\text {soil }}$

total energy ( $A$ ) after transplantation of rice until last irrigation for flooded rice paddy pixels is

$$
A=A_{\text {canopy }}+A_{\text {openwater }}
$$

The PM equation is used to calculate vegetation transpiration as

$$
\lambda E_{\text {canopy }}=\frac{\Delta A_{\text {canopy }}+\rho C_{p}\left(e_{s a t}-e\right) \times g_{a}}{\Delta+\gamma\left(1+g_{a} / g_{s}\right)},
$$




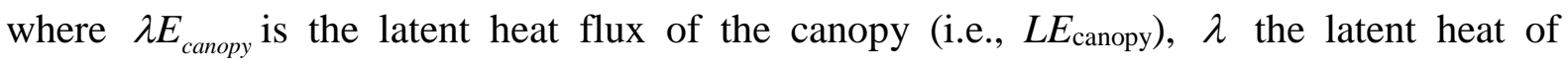
vaporization, $\rho\left(\mathrm{kg} \mathrm{m}^{-3}\right)$ the air density, $\Delta=d e_{\text {sat }} / d T$ the slope of the curve relating saturated water vapour pressure $e_{\text {sat }}$ to air temperature $(\mathrm{T}), e_{\text {sat }}-e$ is the vapour pressure deficit $(V P D), C_{p}\left(\mathrm{~J} \mathrm{~kg}^{-1} \mathrm{~K}^{-1}\right)$ the specific heat capacity of air, $\gamma$ is psychometric constant, and $g_{a}\left(\mathrm{~ms}^{-1}\right)$ the aerodynamic conductance, $g_{s}$ a term identical to canopy conductance $g_{c}$.

Soil evaporation is calculated using equation from Teluguntla et al. (2013) and Zhang et al. (2010), which is a combination of a complementary relationship suggested by Bouchet (1963) and the adjusted PM equation. The soil evaporation equation is

$$
\lambda E_{\text {Soil }}=\frac{\Delta A_{\text {Soil }}+\rho C_{p} V P D g_{a}}{\Delta+\gamma \times\left(g_{a} / g_{\text {totc }}\right)} \times(R H / 10)^{(V P D / k)}
$$

where $(R H / 100)^{(V P D / k)}$ a moisture constraint on soil evaporation, which is an index of soil water deficit based on the complementary relationship where surface moisture status is linked to the evaporative demand of the atmosphere. The theory was that the soil moisture is reflected in the adjacent atmospheric moisture and $R H$ is the relative humidity (\%), $k(\mathrm{~Pa})$ is a parameter to fit the complementary relationship and reflects the relative sensitivity to VPD. It is adjusted for different vegetation types.

$g_{a}$ is sum of $g_{r h}$ and $g_{c h}, g_{r h}(\mathrm{~m} / \mathrm{s})$ is the conductance to the radiative heat transfer,$g_{c h}$ $(\mathrm{m} / \mathrm{s})$ is the conductance to the convective heat transfer under the boundary layer conditions ( $g_{b l}$ ) and assigned $g_{b l}$ and $g_{c h}$ as biome-specific constants. The $g_{\text {tot }}(\mathrm{m} / \mathrm{s})$ is the total aerodynamic conductance to vapour transport and the combination of aerodynamic and 
surface conductance components. The $g_{\text {totc }}(\mathrm{m} / \mathrm{s})$ is the corrected value for $g_{\text {tot }}$ from the standard conditions for temperature and pressure (STP) using the correction coefficient, and $g_{\text {tot }}$ is adjusted by land cover types.

Open water evaporation for flooded paddy rice pixels is calculated using the following equation

$$
\lambda E_{\text {openwater }}=a \frac{\Delta A_{\text {openwater }}}{\Delta+\gamma}
$$




\section{Results and Discussions}

During the study period 2000-01 to 2006-07, actual evapotranspiration estimated using MODIS 250-m data, and daily meteorological data was used with the modified PM equation in two separate schemes. The first one considered flooded rice paddies (denoted by scheme1 hereafter) and the other scheme without considering rice paddies (denoted by scheme2 hereafter). In scheme1, we calculated daily ET using a new model described in section 3, which included vegetation transpiration, soil evaporation and fraction of open water evaporation from flooded rice paddies based on crop calendar. In scheme2, daily ET was estimated without considering flooded rice paddies (as defined in Teluguntla et al., 2013).

First, the hydrological year (June-May) of the study area was divided into two cropping seasons to calculate seasonal ET, namely kharif and rabi. Season 1 (kharif) had 195 days (June 1st to mid-December), which included some fallow period before planting the crop and after harvesting the crop. Season 2 (rabi) had 170 days (mid-December to May 31 ${ }^{\text {st }}$ ) which included some fallow period before planting the crop and after harvesting the crop. Subsequently, daily ET was converted into seasonal ET for both kharif and rabi seasons. Consequently, annual ET was calculated for the hydrological year 2000-01 for the study area. Before estimation of ET, we had derived spatially distributed flooded rice paddy maps for the kharif and the rabi seasons separately using MODIS time series imagery data according to the algorithm developed by Teluguntla et al., (2015).

\subsection{Comparison between ET from two schemes over flooded rice paddy pixels and sensitivities of difference to kharif and rabi}

This article is protected by copyright. All rights reserved. 
For seasonal comparison of estimated ET, we have classified flooded rice paddy pixels into three categories including: 1) kharif season single crop rice, 2) rabi season single crop rice, and 3) both kharif and rabi seasons double crop rice. ET estimated using scheme 1 over flooded rice paddy pixels during kharif season ranged between 700 - $745 \mathrm{~mm} / \mathrm{season}$ with an average of $735 \mathrm{~mm} / \mathrm{season}$. Whereas ET estimated using scheme 2 ranged between 400 - 460 $\mathrm{mm} / \mathrm{season}$ with the average resulting in $440 \mathrm{~mm} / \mathrm{season}$. This showed that approximately $295 \mathrm{~mm}$ of ET was under-estimated for the flooded rice paddy pixels during the kharif season

using scheme 2. Similarly, for the rabi season, scheme 1 ET ranged from 565 - 635 $\mathrm{mm} / \mathrm{season}$ with an average of $590 \mathrm{~mm} / \mathrm{season}$, and scheme 2 ET ranged from 320 - 380 $\mathrm{mm} / \mathrm{season}$ with an average of $340 \mathrm{~mm} / \mathrm{season}$. This showed that approximately 250 $\mathrm{mm} /$ season of ET was under-estimated for the flooded rice paddy pixels during the rabi season using scheme 2.

For double crop rice pixels, scheme 1 ET ranged between 1270 - 1345 mm/year with a mean of $1325 \mathrm{~mm} /$ year. Whereas scheme 2 ET ranged from 700 - $840 \mathrm{~mm} / \mathrm{season}$ with a mean of $780 \mathrm{~mm} /$ season. This showed that approximately $545 \mathrm{~mm} /$ year ET was underestimated for double crop rice area using the scheme 2 ET model.

\subsection{Validation of ET from field studies.}

This study relied on literature for field ET validation; no field level ET measurements were directly made due to lack of field equipment. Based on available literature, ET estimated for flooded rice paddy pixels using scheme 1 were compared with field level actual evapotranspiration (ETa) measured/observed using flux tower studies by Alberto et al., 2011. 
Observed ET for the wet season ( kharif season) rice was $800 \mathrm{~mm}$, which was measured for 211 days that included some fallow period; and dry season ( rabi season) rice ET was 592 mm for 155 days that also included some fallow period. The total ET observed for double crop rice was $1392 \mathrm{~mm}$ for 365 days. Annual ET estimated (double crop rice ET) from the current study was $1325 \mathrm{~mm} /$ year (Table 2) which is very close to the observed ET values from field studies. Season wise ET estimates are also very close to the observed values. 


\subsection{Impact of including flooded-rice paddy-specific scheme on the basin-scale ET estimates}

First, spatially distributed flooded rice paddy maps for kharif and rabi seasons were derived separately from MODIS imagery according to the procedure developed by Teluguntla et al., 2015. Figure 2a shows spatially distributed flooded rice paddy maps for kharif, rabi and annual (kharif + rabi) respectively for the growing season of 2000-01. Figure 2b shows spatially distributed ET maps for kharif, rabi and annual (kharif + rabi) respectively, which considered open water evaporation from flooded rice paddies for the year 2000-01. ET estimated using scheme1 was $463 \mathrm{~mm}$ for kharif season, $307 \mathrm{~mm}$ for rabi season and $770 \mathrm{~mm} /$ year for the year of 2000-01. Scheme 1 annual ET was $38 \mathrm{~mm} /$ year higher than ET estimated using Scheme 2, which was $732 \mathrm{~mm} /$ year. Annual ET comparisons from both schemes are shown in Figure 3.

Similarly, seasonal ET comparisons between the two schemes are shown in Figure 4 and Figure 5. The maximum difference was observed in the kharif season, which was about a 31 mm difference when compared to basin scale ET, while an 8mm difference was observed in the rabi season. During the kharif season, scheme1 ET showed $463 \mathrm{~mm} / \mathrm{season}$ and scheme 2 ET showed $432 \mathrm{~mm} /$ season (Figure 4). During the rabi season, scheme1 ET was estimated at $307 \mathrm{~mm} / \mathrm{season}$, while scheme $2 \mathrm{ET}$ was estimated at $299 \mathrm{~mm} /$ season (Figure 5). This resulted in that the flooded rice paddy area during the kharif season was higher than the rabi season. This implies that the estimated ET of flooded rice paddies was higher during the kharif season. In fact, there are huge amounts of fields cultivated with flooded rice paddies during the kharif season especially in the downstream section of the basin. Consequently, 
there is a large variation in estimated ET between the two ET schemes over flooded rice paddy pixels.

To compare ET between the two models, we have calculated basin scale daily ET using two schemes for the hydrological years 2000-01 to 2006-07, shown as annual ET in Table 3. This analysis found that there was a $17 \mathrm{~mm} /$ year difference in average annual ET between the two models, which is $2.36 \%$ of basin ET. The maximum difference between the two schemes was observed in 2000-01, which was $38 \mathrm{~mm} /$ year (5.19\% of Basin ET) and the minimum difference was observed in 2003-04, which was $7 \mathrm{~mm} /$ year (1.01\% of Basin ET). This difference is due to fluctuations in annual rainfall in the study area. The 2000-01 hydrological year was relatively wet year (Gumma et al., 2011a) in the Krishna River Basin and year 2003-04 was the worst drought year in the basin during our study period (Teluguntla et al., 2015). Rice cropped area was high during the year 2000-01, due to surplus water supply for the rice crop. Rice cropped area significantly dropped during the year 2003-04 due to a water deficit in the basin. District wise agricultural statistics from Department of Agriculture also found a significant difference in rice cropped area between the above two years (Teluguntla et al., 2015).

\section{Summary and Conclusions}

This study has shown that underestimation of ET can occur due to the open water evaporation from flooded rice paddies ignored in existing ET models. To address the gap in ET estimation, we have developed a novel approach that accounts for the missing ET component over flooded rice paddies. Our method improved ET estimates by a modified Penman-Montieth (PM) algorithm that considered the fraction of open water evaporation 
from flooded rice paddies. Evapotranspiration was calculated using the MODIS imagery and daily local meteorological data over the Krishna River Basin. Daily time series of ET maps were prepared using two ET models. Seasonal and annual ET over the Krishna River Basin was compared with two different schemes of ET algorithms. ET was also compared for different crop combinations. Results were validated with flux tower-based measurements from other studies. We have identified a $17 \mathrm{~mm} /$ year difference in average annual ET over the Krishna River Basin with a new ET algorithm. This is very critical in basin scale water balance analysis and water productivity studies in semi-arid regions. Although we applied this novel approach in the Krishna River Basin, the methodology developed here is not geographically limited to this study region. It can be applied in any other catchments with similar climates across the globe. This approach can be extended to larger regions such as sub-continental to continental scales if the required meteorological and landcover data are available. This study has shown that a robust evapotranspiration estimate can be derived for flooded rice paddies; this methodology should be replicated in other rice paddy growing areas for further validation.

\section{Acknowledgements}

The authors would like to thank two anonymous reviewers and associate editor of HYP journal for providing constructive comments for the improvement of the manuscript. The research is funded by the ACIAR under the John Allwright Fellowship and the ACIAR Project LWR-2007-113. The authors would like to thank the International Water Management Institute (IWMI), International Crops Research Institute for Semi-Arid and Tropics (ICRISAT), Central Research Institute for Dry land Agriculture (CRIDA), the Indian 
Meteorological Department (IMD), and the Indian Institute of Tropical Meteorology (IITM) for providing daily ground meteorological and other ancillary data.

\section{Data Availability Statement}

The data generated for this study is available from the corresponding author upon realistic request.

This article is protected by copyright. All rights reserved. 


\section{List of Figures}

Figure1: Location map of the study area with ground meteorological stations and river network generated using SRTM 90m DEM.

Figure 2: a) Season wise rice paddy maps for the year 2000-01 derived using Teluguntla et al., 2015 (upper panel). b) Season wise ET maps for the year 2000-01 derived using new ET model by considering flooded rice paddies (lower panel).

Figure 3: Comparison of spatially distributed annual ET maps of Krishna River Basin for the year 2000-01. a) ET Map with flooded paddies ignored (left panel, b) ET Map with flooded paddies considered (right panel).

Figure 4: Comparison of spatially distributed ET maps of Krishna River Basin during 200001 kharif season. a) ET Map with flooded paddies ignored (left panel), b) ET Map with flooded paddies considered (right panel).

Figure 5: Comparison of spatially distributed ET maps of Krishna River Basin during 200001 rabi season. a) ET Map with flooded paddies ignored (left panel), b) ET Map with flooded paddies considered (right panel).

\section{List of Tables}

Table 1: Specifications of the MODIS-Terra bands used for calculation of required indices for this study ${ }^{1}$.

Table 2: Range and average ET of flooded rice paddy pixels estimated using two evapotranspiration models (with and without considering fraction of open evaporation from flooded paddy pixels).

Table 3: Comparison of annual ET estimated from two models (2000-01 to 2006-07). 


\section{References}

Alberto, M.C.R., Wassmann, R., Hirano, T., Miyata, A., Hatano, R., Kumar, A., Padre, A. and Amante, M., 2011. Comparisons of energy balance and evapotranspiration between flooded and aerobic rice fields in the Philippines. Agricultural Water Management, 98(9), pp.1417-1430.

Allen, R. G., L. A. Pereira, D. Raes, et al. 1998. Crop evapotranspiration guidelines for computing crop water requirements. FAO Irrigation and Drainage Paper-56, FAO, Rome.

Allen, R. G., M. Tasumi, R. Trezza, et al. 2007a. Satellite-based energy balance for mapping evapotranspiration with internalized calibration (METRIC) model. Journal of Irrigation and Drainage Engineering 133:380-394.

Allen, R. G., M. Tasumi, R. Trezza, et al. 2007b. Satellite-based energy balance for mapping evapotranspiration with internalized calibration (METRIC) applications. Journal of Irrigation and Drainage Engineering 133:395-406.

Bastiaanssen, W. G. M., M. Menenti, R. A. Feddes, et al. 1998a. A remote sensing surface energy balance algorithm for land (SEBAL): Part I Formulation. Journal of Hydrology 213:198-212.

Bastiaanssen, W. G. M., H. Pelgrum, J. Wang, et al. 1998b. A remote sensing surface energy balance algorithm for land (SEBAL): Part II validation. International Journal of Hydrology 213:213-229.

Bastiaanssen, W.G., Molden, D.J. and Makin, I.W., 2000. Remote sensing for irrigated agriculture: examples from research and possible applications. Agricultural water management, 46(2), pp.137-155.

Bastiaanssen, W.G.M., Noordman, E.J.M., Pelgrum, H., Davids, G., Thoreson, B.P. and Allen, R.G., 2005. SEBAL model with remotely sensed data to improve waterresources management under actual field conditions. Journal of irrigation and drainage engineering, 131(1), pp.85-93.

Biggs, T., P. Thenkabail, M. Gumma, C. Scott, G. Parthasaradhi and H. Turral (2006). Irrigated area mapping in heterogeneous landscapes with MODIS time series, ground truth and census data, Krishna Basin, India. International Journal of Remote Sensing 27(19): 4245-4266.

Bouchet, R. J. (1963), Evapotranspiration réelle evapotranspiration potentielle, signification climatique, Proc. Berkeley Calif. Symposium. IAHS 62:132-142

Cleugh, H. A., R. Leuning, Q. Mu, et al. 2007. Regional evaporation estimates from flux tower and MODIS satellite data. Remote Sensing of Environment 106:285-304.

FAO : http://www.fao.org/3/a-i3084e/i3084e18.pdf

Ferguson, C. R., J. Sheffield, E. F. Wood, et al. 2010. Quantifying uncertainty in a remote sensing-based estimate of evapotranspiration over continental USA. International Journal of Remote Sensing 31:3821-3865.

Gumma, M.K., Thenkabail, P.S., Muralikrishna, I.V., Velpuri, M.N., Gangadhararao, P.T., Dheeravath, V., Biradar, C.M., Acharya Nalan, S. and Gaur, A., 2011a. Changes in agricultural cropland areas between a water-surplus year and a water-deficit year 
impacting food security, determined using MODIS $250 \mathrm{~m}$ time-series data and spectral matching techniques, in the Krishna River basin (India). International Journal of Remote Sensing, 32(12), pp.3495-3520.

Gumma, M.K., Thenkabail, P.S. and Nelson, A., 2011b. Mapping irrigated areas using MODIS 250-meter time-series data: A study on Krishna River Basin (India). Water, 3(1), pp.113-131.

Gumma, M.K., Nelson, A., Thenkabail, P.S. and Singh, A.N., 2011c. Mapping rice areas of South Asia using MODIS multitemporal data. Journal of applied remote sensing, 5(1), p.053547.

Jamshidi, S., Zand-parsa, S., Pakparvar, M. and Niyogi, D., 2019. Evaluation of Evapotranspiration over a Semiarid Region Using Multiresolution Data Sources. Journal of Hydrometeorology, 20(5), pp.947-964.

Kalma, J. D., T. R. McVicar and M. F. McCabe. 2008. Estimating land surface evaporation: A review of methods using remotely sensed surface temperature data. Surveys in Geophysics 29(4-5): 421-469.

Kustas, W. P., F. Li, T. J. Jackson, et al. 2004. Effects of remote sensing pixel resolution on modeled energy flux variability of croplands in Iowa. Remote Sensing of Environment 92:535-547.

Kustas, W. P., J. M. Norman, M. C. Anderson, et al. 2003. Estimating sub pixel surface temperatures and energy fluxes from the vegetation index-radiometric temperature relationship. Remote Sensing of Environment 85:429-440.

Leuning, R., Y. Q. Zhang, A. Rajaud, et al. 2008. A simple surface conductance model to estimate regional evaporation using MODIS leaf area index and the Penman-Monteith equation. Water Resources Research. 44, W10419.

Li, Z.L., Tang, R., Wan, Z., Bi, Y., Zhou, C., Tang, B., Yan, G. and Zhang, X., 2009. A review of current methodologies for regional evapotranspiration estimation from remotely sensed data. Sensors, 9(5), pp.3801-3853.

Marek, T., Piccinni, G., Schneider, A., Howell, T., Jett, M., \& Dusek, D. (2006). Weighing lysimeters for the determination of crop water requirements and crop coefficients. Applied Engineering in Agriculture, 22(6), 851-856.

Mu, Q., F. A. Heinsch, M. Zhao, et al. 2007. Development of a global evapotranspiration algorithm based on MODIS and global meteorology data. Remote Sensing of Environment 111:519-536.

Mu, Q., Zhao, M. and Running, S.W., 2011. Improvements to a MODIS global terrestrial evapotranspiration algorithm. Remote Sensing of Environment, 115(8), pp.17811800.

Mutert, E. and Fairhurst, T.H. 2002. Developments in rice production in Southeast Asia. Better Crops International, 15.

Moratiel, R. and Martínez-Cob, A., 2013. Evapotranspiration and crop coefficients of rice (Oryza sativa L.) under sprinkler irrigation in a semiarid climate determined by the surface renewal method. Irrigation science, 31(3), pp.411-422. 
Priestley, C. H. B., \& Taylor, R. J. 1972. On the assessment of surface heat flux and evaporation using large scale parameters. Monthly Weather Review, 100: 81-92.

Samarendu Mohanty, IRRI, 2014. Rice Today Vol. 13, No. 2 Rice in South Asia http://irri.org/rice-today/rice-in-south-asia

Senay, G.B., Budde, M., Verdin, J.P. and Melesse, A.M., 2007. A coupled remote sensing and simplified surface energy balance approach to estimate actual evapotranspiration from irrigated fields. Sensors, 7(6), pp.979-1000.

Senay, G. B., Bohms, S., Singh, R. K., Gowda, P. H., Velpuri, N. M., Alemu, H., et al. (2013). Operational evapotranspiration mapping using remote sensing andweather datasets:A new parameterization for the SSEB approach. Journal of the American Water Resources Association, 1-15, http://dx.doi.org/10.1111/jawr.12057.

Su, Z. 2002. The Surface Energy Balance System (SEBS) for estimation of turbulent heat fluxes, Hydrology Earth System Science 6:85-99.

Shuttleworth, W.J. and Wallace, J.S., 1985. Evaporation from sparse crops-an energy combination theory. Quarterly Journal of the Royal Meteorological Society, 111(469), pp.839-855.

Tasumi, M., R. Allen, R. G. Trezza, et al. 2005. Satellite-based energy balance to assess within-population variance of crop coefficient curves. Journal of Irrigation and Drainage Engineering 13:94-109.

Teluguntla, P., Ryu, D., George, B., \& Walker, J. P. (2013). Multidecadal trend of basin-scale evapotranspiration estimated using AVHRR data in the Krishna River Basin, India. Vadose Zone Journal, 12(3).

Teluguntla, P., D. Ryu, B. George, J. P. Walker and H. M. Malano (2015). "Mapping Flooded Rice Paddies Using Time Series of MODIS Imagery in the Krishna River Basin, India." Remote Sensing 7(7): 8858-8882.

Thenkabail, P. S., P. Gangadhararao, T. Biggs, et al. 2007. Spectral matching techniques to determine historical land use/land cover (LULC) and irrigated areas using time-series AVHRR Pathfinder datasets, Photogrammetric Engineering \& Remote Sensing 73:1029-1040.

Vinukollu, R. K., E. F. Wood, C. R. Ferguson, et al. 2011. Global estimates of evapotranspiration for climate studies using multi-sensor remote sensing data: Evaluation of three process-based approaches. Remote Sensing of Environment 115:801-823.

Wessel, D.A. and Rouse, W.R., 1994. Modelling evaporation from wetland tundra. Boundary-Layer Meteorology, 68(1-2), pp.109-130.

Zhang, K., J. S. Kimball, Q. Mu, et al. 2009. Satellite based analysis of northern ET trends and associated changes in the regional water balance from 1983 to 2005. Journal of Hydrology 379:92-110.

Zhang, K., J. S. Kimball, R. R. Nemani, et al. 2010. A continuous satellite derived global record of land surface evapotranspiration from 1983 to 2006. Water Resources Research 46, W09522. 


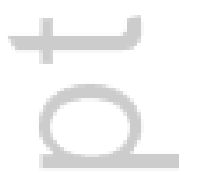

4 


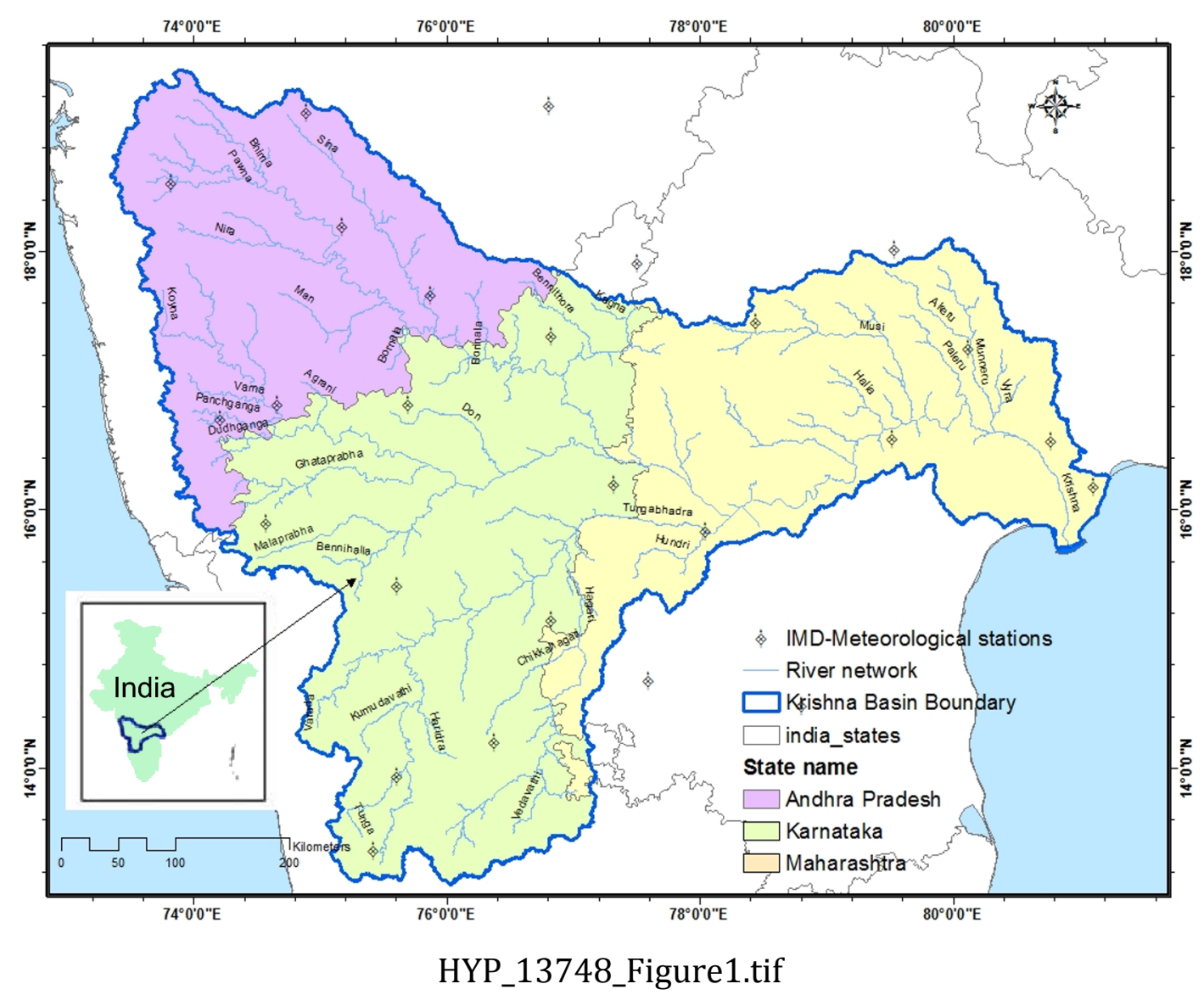

This article is protected by copyright. All rights reserved. 

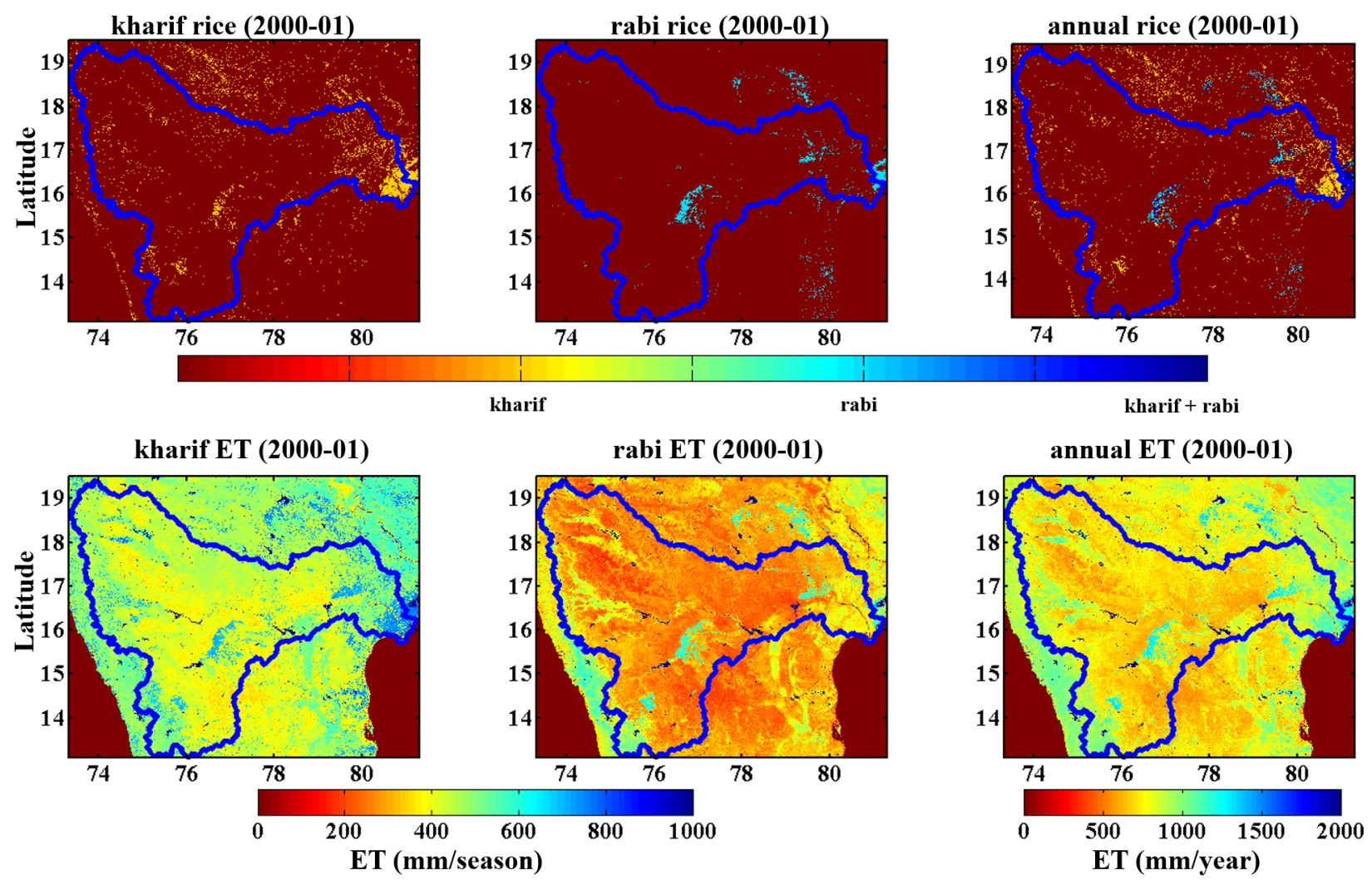

HYP_13748_Figure2.tif 


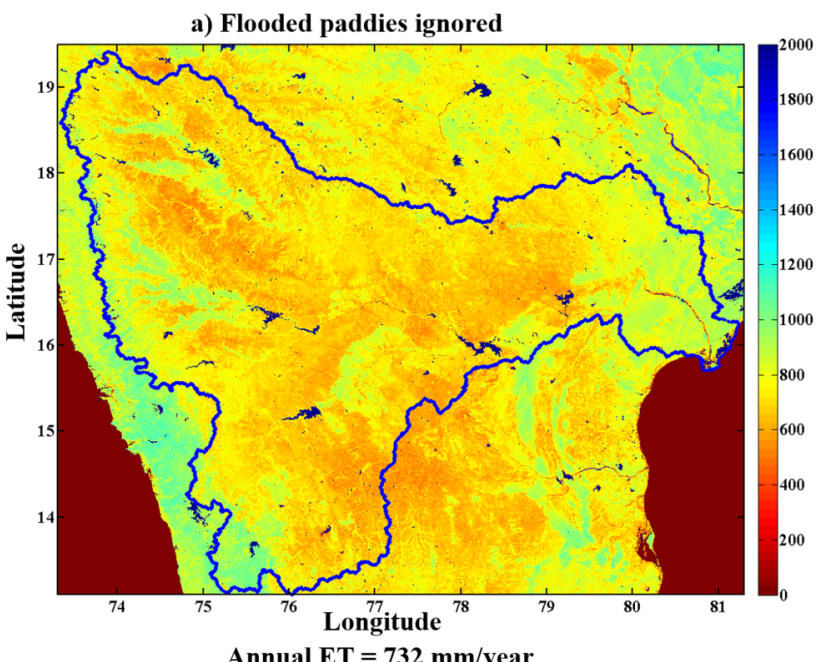

Annual ET $=732 \mathrm{~mm} /$ year b) Flooded paddies considered

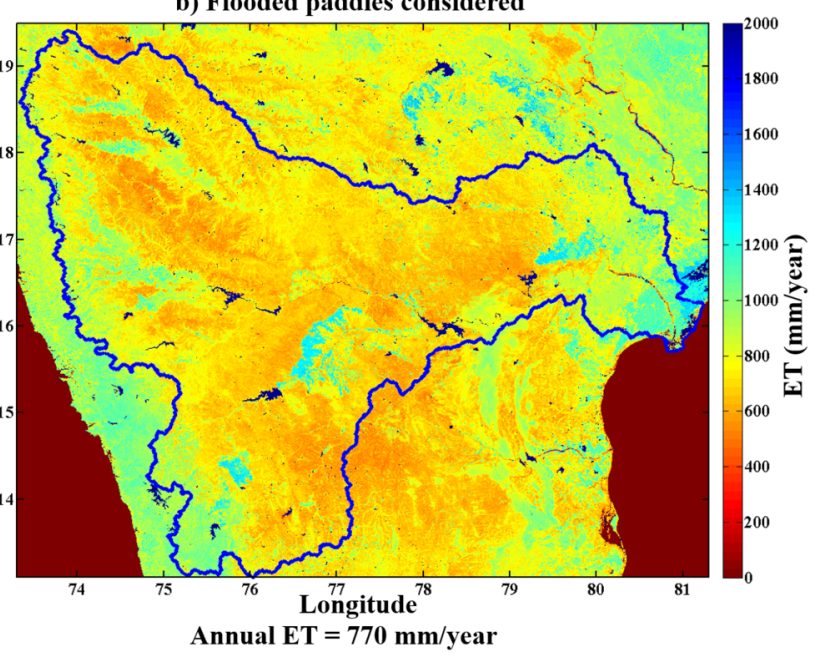

HYP_13748_Figure3.tif

This article is protected by copyright. All rights reserved. 


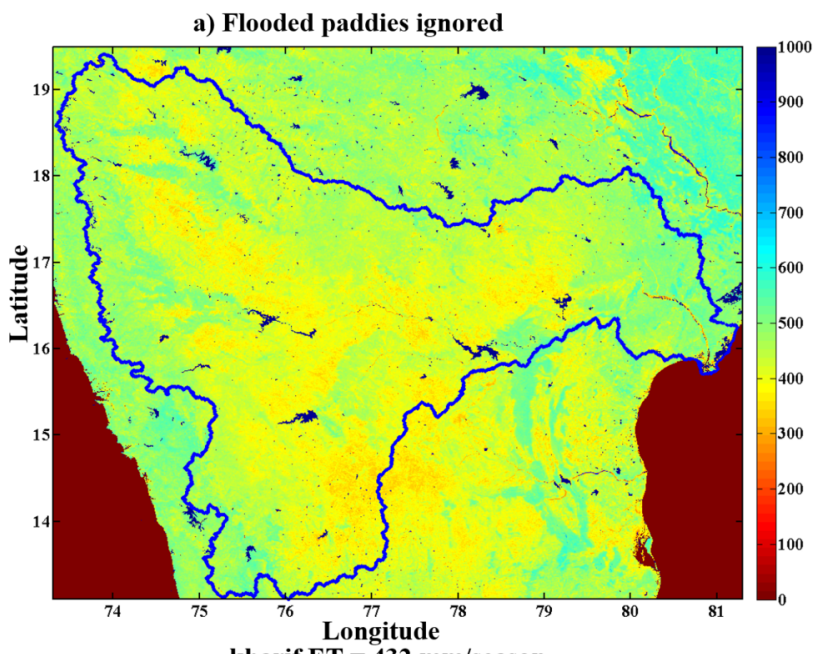

kharif ET $=432 \mathrm{~mm} /$ season

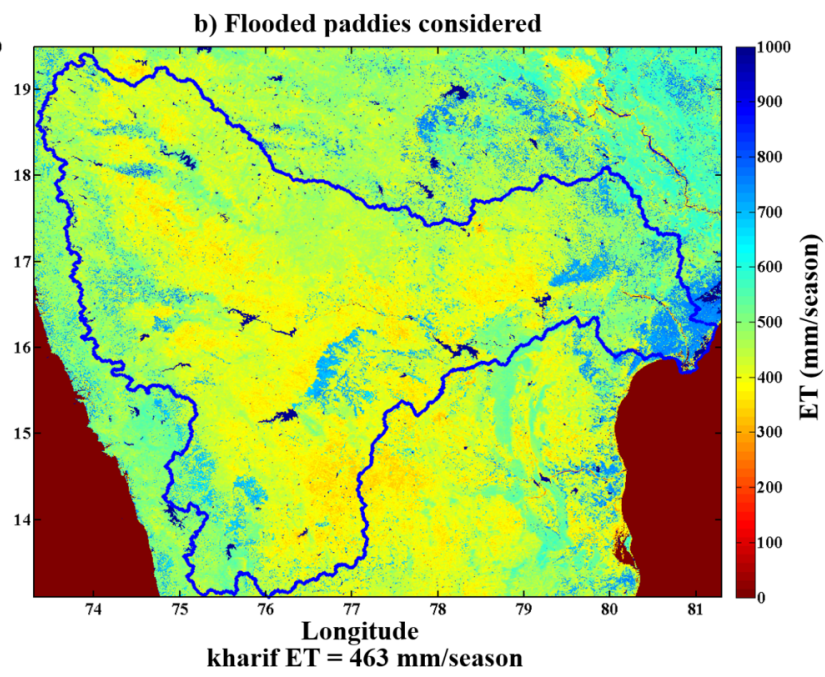

kharif ET $=463 \mathrm{~mm} / \mathrm{season}$

HYP_13748_Figure4.tif 
a) Flooded paddies ignored

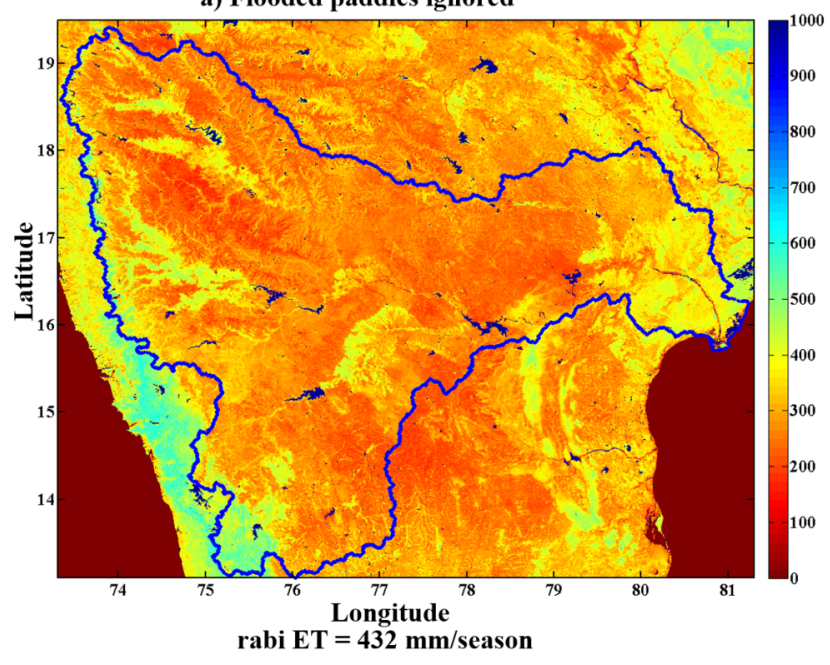

b) Flooded paddies considered

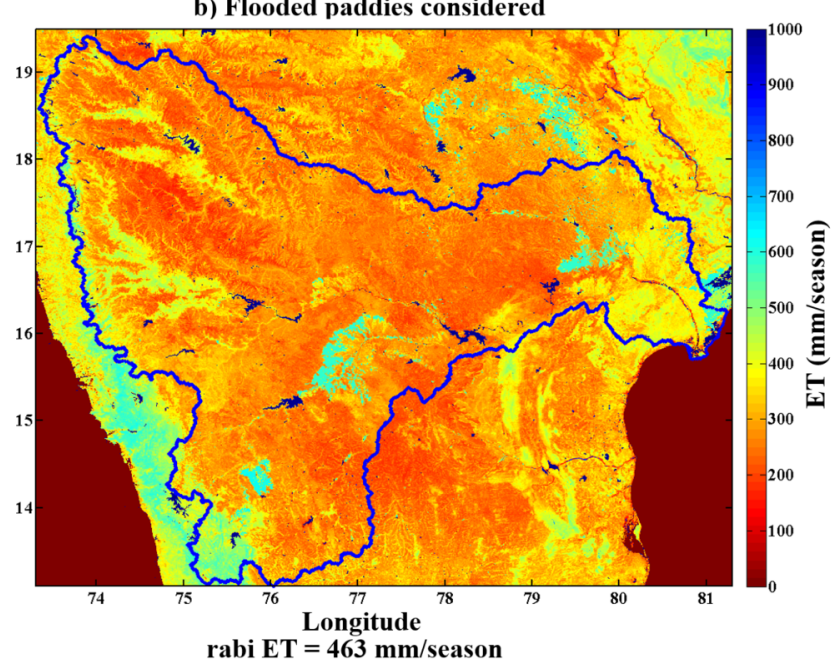

HYP_13748_Figure5.tif

This article is protected by copyright. All rights reserved. 


\title{
Title:
}

\section{Impact of flooded rice paddy on remotely sensed evapotranspiration in the Krishna River Basin, India}

\author{
Pardhasaradhi Teluguntla $^{1^{*}}$, Dongryeol Ryu ${ }^{1 *}$, Biju George ${ }^{1}$ and Jeffrey P. Walker ${ }^{2}$ \\ ${ }^{1}$ Department of Infrastructure Engineering, The University of Melbourne, Victoria, Australia; \\ E-Mails: teluguntlasaradhi@gmail.com; dryu@unimelb.edu.au; biju@unimelb.edu.au \\ ${ }^{2}$ Department of Civil Engineering, Monash University, Victoria, Australia; E-Mail: jeff.walker@monash.edu; \\ *Author to whom correspondence should be addressed; E-Mail: \\ teluguntlasaradhi@gmail.com;dryu@unimelb.edu.au
}

\section{Running title:}

Impact of flooded rice paddy on remotely sensed evapotranspiration

This article is protected by copyright. All rights reserved. 


\section{Key Findings:}

1. Identified gaps in existing remote sensing evapotranspiration (ET) models resulting in under estimation of ET in semi-arid regions.

2. We showed underestimation of ET can be occur due to the open water evaporation from flooded rice paddies ignored in the existing ET models.

3. Developed a novel approach that accounts for the missing ET component over flooded rice paddies. Which is very critical in basin scale water balance in semi-arid regions. 

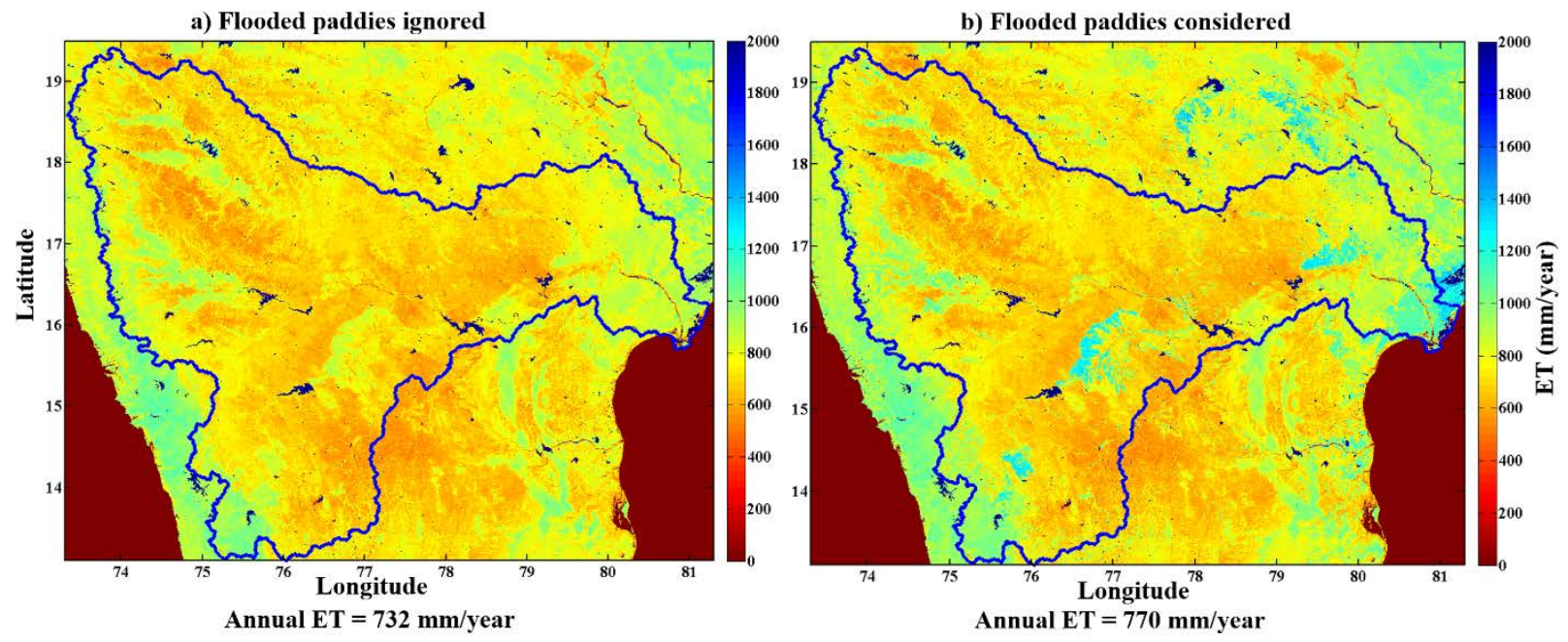

This article is protected by copyright. All rights reserved. 


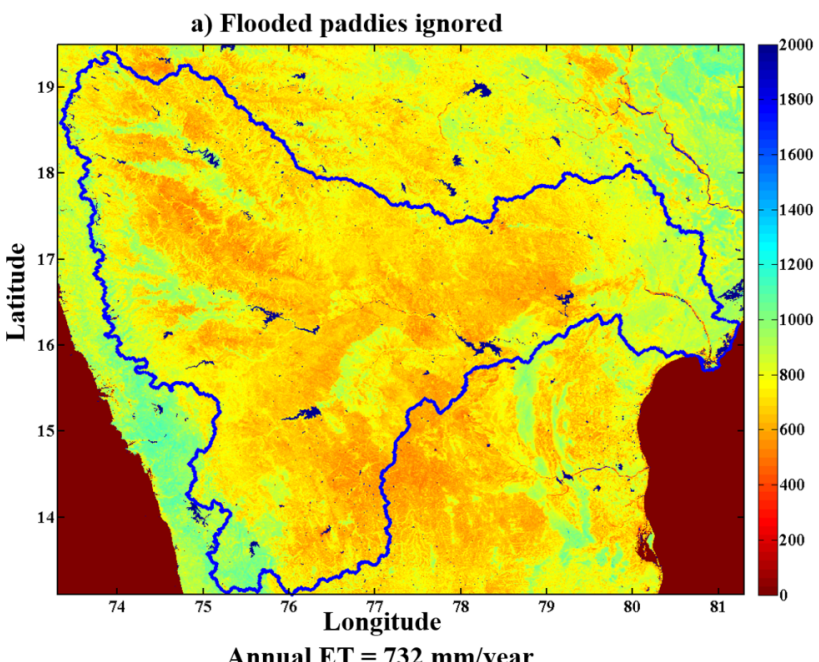

Annual ET $=732 \mathrm{~mm} /$ year b) Flooded paddies considered

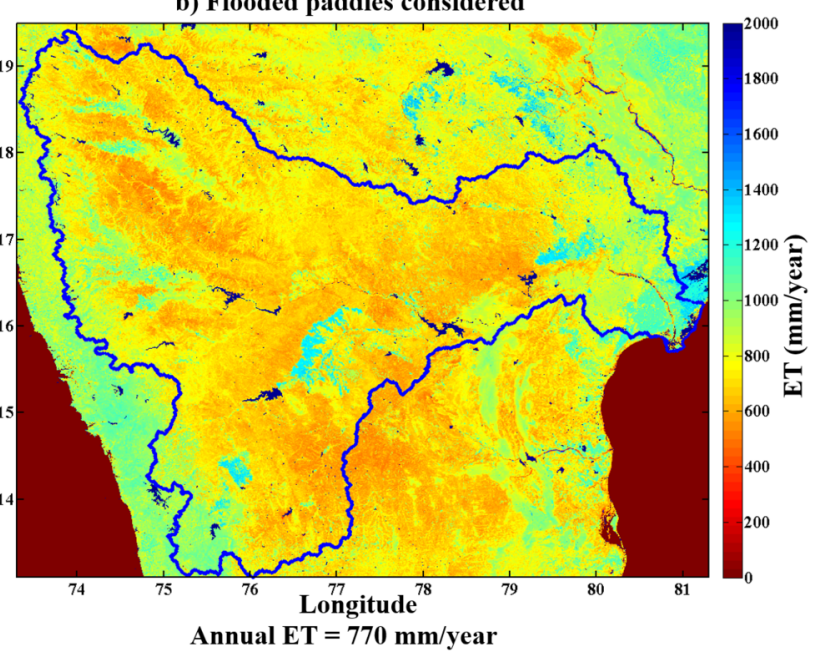

HYP_13748_Graphical-Abstract-HYP-19-0909-R1.tif 
Table 1: Specifications of the MODIS-Terra bands used for calculation of required indices for this study ${ }^{1}$

\begin{tabular}{cccccc}
\hline $\begin{array}{c}\text { MODIS } \\
\text { bands }\end{array}$ & $\begin{array}{c}\text { Sub- } \\
\text { division }\end{array}$ & $\begin{array}{c}\text { Band } \\
\text { width } \\
\text { (nm) }\end{array}$ & $\begin{array}{c}\text { Band center } \\
\text { wavelength } \\
\mathbf{( n m )}\end{array}$ & $\begin{array}{c}\text { Spatial } \\
\text { resolution } \\
\mathbf{( m )}\end{array}$ & $\begin{array}{c}\text { MODIS } \\
\text { product }\end{array}$ \\
\hline 1 & red & $620-670$ & 648 & $250 \mathrm{~m}$ & MOD09Q1 \\
2 & NIR & $841-876$ & 858 & $250 \mathrm{~m}$ & MOD09Q1 \\
3 & blue & $459-479$ & 470 & $500 \mathrm{~m}$ & MOD09A1 \\
6 & SWIR & $1628-1652$ & 1640 & $500 \mathrm{~m}$ & MOD09A1 \\
\hline
\end{tabular}

Note:

${ }^{1}$ MODIS acquire data in 36 spectral bands, out of which the first 7 bands are specially designed for land studies. We have used band 1, band 2, band 3 and band 6 in this study. Source: http://modis-land.gsfc.nasa.gov 
Table 2: Range and average ET of flooded rice paddy pixels estimated using two evapotranspiration models (with and without considering fraction of open evaporation from flooded paddy pixels).

\begin{tabular}{|c|c|c|c|c|}
\hline Category & & $\begin{array}{c}\text { ET includes } \\
\text { open water evaporation } \\
\text { from flooded rice paddy } \\
\text { (new ET model) }\end{array}$ & $\begin{array}{l}\text { ET without including } \\
\text { open water evaporation } \\
\text { from flooded rice paddy } \\
\text { (old ET model) }\end{array}$ & Difference \\
\hline \multirow{2}{*}{$\begin{array}{c}\text { kharif rice } \\
\text { (single crop rice) }\end{array}$} & Range (mm) & $700-745$ & $400-460$ & $285-300$ \\
\hline & Average (mm) & 735 & 440 & 295 \\
\hline \multirow{2}{*}{$\begin{array}{c}\text { rabi rice } \\
\text { (single crop rice) }\end{array}$} & Range (mm) & $560-635$ & $320-380$ & $240-255$ \\
\hline & Average (mm) & 590 & 340 & 250 \\
\hline \multirow{2}{*}{$\begin{array}{l}\text { kharif + rabi rice } \\
\text { (double crop rice) }\end{array}$} & Range(mm) & $1270-1345$ & $700-840$ & $500-570$ \\
\hline & Average (mm) & 1325 & 780 & 545 \\
\hline
\end{tabular}

This article is protected by copyright. All rights reserved. 
Table 3: Comparison of annual ET estimated from two models (2000-01 to 2006-07).

\begin{tabular}{ccccc}
\hline Year & $\begin{array}{c}\text { ET includes } \\
\text { open water evaporation } \\
\text { from flooded rice paddy } \\
\text { Scheme 1 } \\
\text { (mm/year) }\end{array}$ & $\begin{array}{c}\text { ET without including } \\
\text { open water evaporation } \\
\text { from flooded rice paddy } \\
\text { Scheme 2 } \\
\text { (mm/year) }\end{array}$ & $\begin{array}{c}\text { ET difference } \\
\text { between the two } \\
\text { models } \\
\text { (mm/year) }\end{array}$ & $\begin{array}{c}\text { Difference } \\
\text { in ET } \\
\text { (\%) }\end{array}$ \\
\hline $2000-01$ & 770 & 732 & 38 & $5.19 \%$ \\
$2001-02$ & 738 & 725 & 13 & $1.79 \%$ \\
$2002-03$ & 713 & 704 & 8 & $1.15 \%$ \\
$2003-04$ & 709 & 702 & 7 & $1.01 \%$ \\
$2004-05$ & 769 & 755 & 14 & $1.87 \%$ \\
$2005-06$ & 768 & 745 & 23 & $3.09 \%$ \\
$2006-07$ & 800 & 781 & 19 & $2.41 \%$ \\
\hline Average change in annual ET with new ET model (mm/year) & $\mathbf{1 7}$ & $\mathbf{2 . 3 6 \%}$ \\
\hline
\end{tabular}

This article is protected by copyright. All rights reserved. 


\section{University Library}

\section{- M M N E R VA A gateway to Melbourne's research publications}

Minerva Access is the Institutional Repository of The University of Melbourne

Author/s:

Teluguntla, P;Ryu, D;George, B;Walker, JP

Title:

Impact of flooded rice paddy on remotely sensed evapotranspiration in the Krishna River basin, India

\section{Date:}

2020-05-15

\section{Citation:}

Teluguntla, P., Ryu, D., George, B. \& Walker, J. P. (2020). Impact of flooded rice paddy on remotely sensed evapotranspiration in the Krishna River basin, India. Hydrological Processes, 34 (10), pp.2190-2199. https://doi.org/10.1002/hyp.13748.

Persistent Link:

http://hdl.handle.net/11343/275568 